\begin{tabular}{|c|c|}
\hline CRITICAL $\underset{\substack{\text { ECOSYSTEM } \\
\text { PARTNERSHIP FUND }}}{ }$ & $\begin{array}{l}\text { Western Ghats } \\
\text { Special Series }\end{array}$ \\
\hline
\end{tabular}

\section{RANGE EXTENSION OF MALABAR TREe NYMPH IDEA MALABARICA (MOORE) (LEPIDOPTERA: NYMPHALIDAE) TO NORTHERN WESTERN GHATS OF MAHARASHTRA AND A REVIEW OF DISTRIBUTION RECORDS}

\author{
Manoj Jadhav ${ }^{1}$ \& R.M. Sharma ${ }^{2}$
}

Zoological Survey of India, Western Regional Centre

Pune, Maharashtra 411044, India

1.jadhav.manoj83@gmail.com (corresponding author), ${ }^{2}$ rmsharma53@yahoo.in

While surveying insects on the outskirts of Bhimashankar Wildlife Sanctuary near Dimbhe Dam $\left(19^{\circ} 5^{\prime} 23^{\prime \prime} \mathrm{N} \& 7^{\circ} 44^{\prime} 31^{\prime \prime} \mathrm{E}\right.$ at $\left.662 \mathrm{~m}\right)$ on 14 April 2012, our attention was caught by a group of three butterflies hovering over Lantana flowers near a stream with their slow and floating flight. One of them was collected using an insect net and preserved (Image 1). It was identified as a Malabar Tree Nymph Idea malabarica (Moore) on the basis of literature, especially Evans (1932), Wynter-Blyth (1957), Kunte (2000) and Kehimkar (2008).

\section{Family: Nymphalidae}

\section{Subfamily: Danainae}

Idea malabarica (Moore) 1877

Material examined: 1 ex, 14.iv.2012, near bridge on road to Dimbhe Dam, Pune District, Maharashtra, coll. Manoj Jadhav (Z.S.I. W.R.C., Pune, Registration No. Ent.02/1110).

\section{Wing span: $112 \mathrm{~mm}$.}

Idea malabarica (Moore) is reported as confined to wet evergreen forests with heavy rainfall areas south of Goa to southern

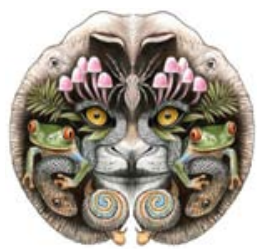

ISSN

Online 0974-7907 Print 0974-7893

\section{OPEN ACCESS} Western Ghats up to Kerala and is endemic to this area (Evans 1932; Wynter-Blyth 1957; Larsen, 1987; Kunte 2000; Rangnekar 2007; Kehimkar 2008; Sharma \& Borkar 2008). Largest among milkweed butterflies, unmistakable due to its slowest flight among Indian butterflies, prefers wetter forests between 300-1200 m in the hills (WynterBlyth 1957).

Barring a single record of Ghosh et al. (1990) from Raigarh District as a new report for Maharashtra State, no further records of Idea malabarica from any of the districts

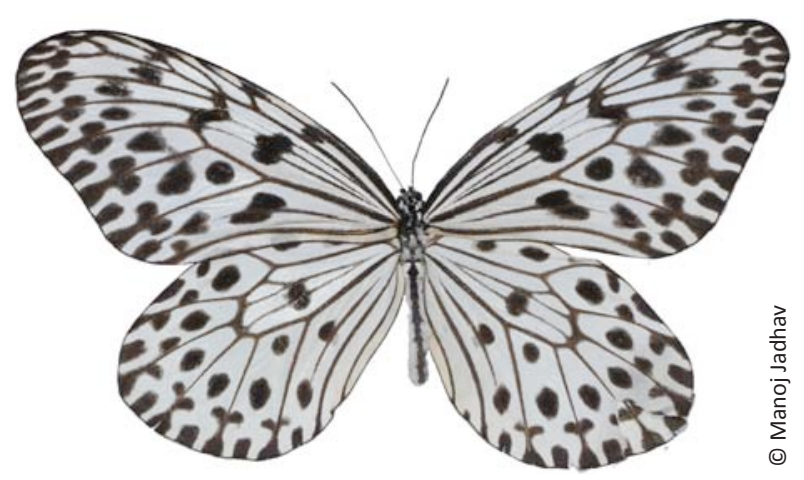

Image 1. Idea malabarica Moore captured at Dimbhe, Pune District

DOI: http://dx.doi.org/10.11609/JoTT.o3267.949 | ZooBank: urn:Isid:zoobank.org:pub:995D8DE3-C460-4CAE-8534-E459B9D7FF02

Manuscript details: Ms \# 03267 | Received 25 July 2012 | Final received 15 October 2012 | Finally accepted 31 December 2012

Citation: Jadhav, M. \& R.M. Sharma (2013). Range extension of Malabar Tree Nymph Idea malabarica (Moore) (Lepidoptera: Nymphalidae) to northern Western Ghats of Maharashtra and a review of distribution records. Journal of Threatened Taxa 5(1): 3556-3558; doi:10.11609/JoTT.03267.949

Copyright: @ Jadhav \& Sharma 2013. Creative Commons Attribution 3.0 Unported License. JoTT allows unrestricted use of this article in any medium, reproduction and distribution by providing adequate credit to the authors and the source of publication.

Funding: In-house study programme.

Competing Interest: None.

Acknowledgements: The authors express their sincere gratitude to Dr. K. Venkataraman, Director, Zoological Survey of India, Kolkata for constant support and providing facilities. We also wish to thank Dr. Muhamed Jafer Palot, Assistant Zoologist, Zoological Survey of India, Calicut for his critical reading, suggestions in improvement of first draft and sparing valuable literature. Our thanks are also due to Dr. Neelesh Dahanukar, Indian Institute of Science, Education and Research, Pune for valuable help rendered in preparing map and Dr. S.S. Jadhav, Senior Zoological Assistant, Zoological Survey of India, Pune for inputs to enhance the quality of the paper.

The publication of this article is supported by the Critical Ecosystem Partnership Fund (CEPF), a joint initiative of I'Agence Française de Développement, Conservation International, the European Commission, the Global Environment Facility, the Government of Japan, the MacArthur Foundation and the World Bank. 


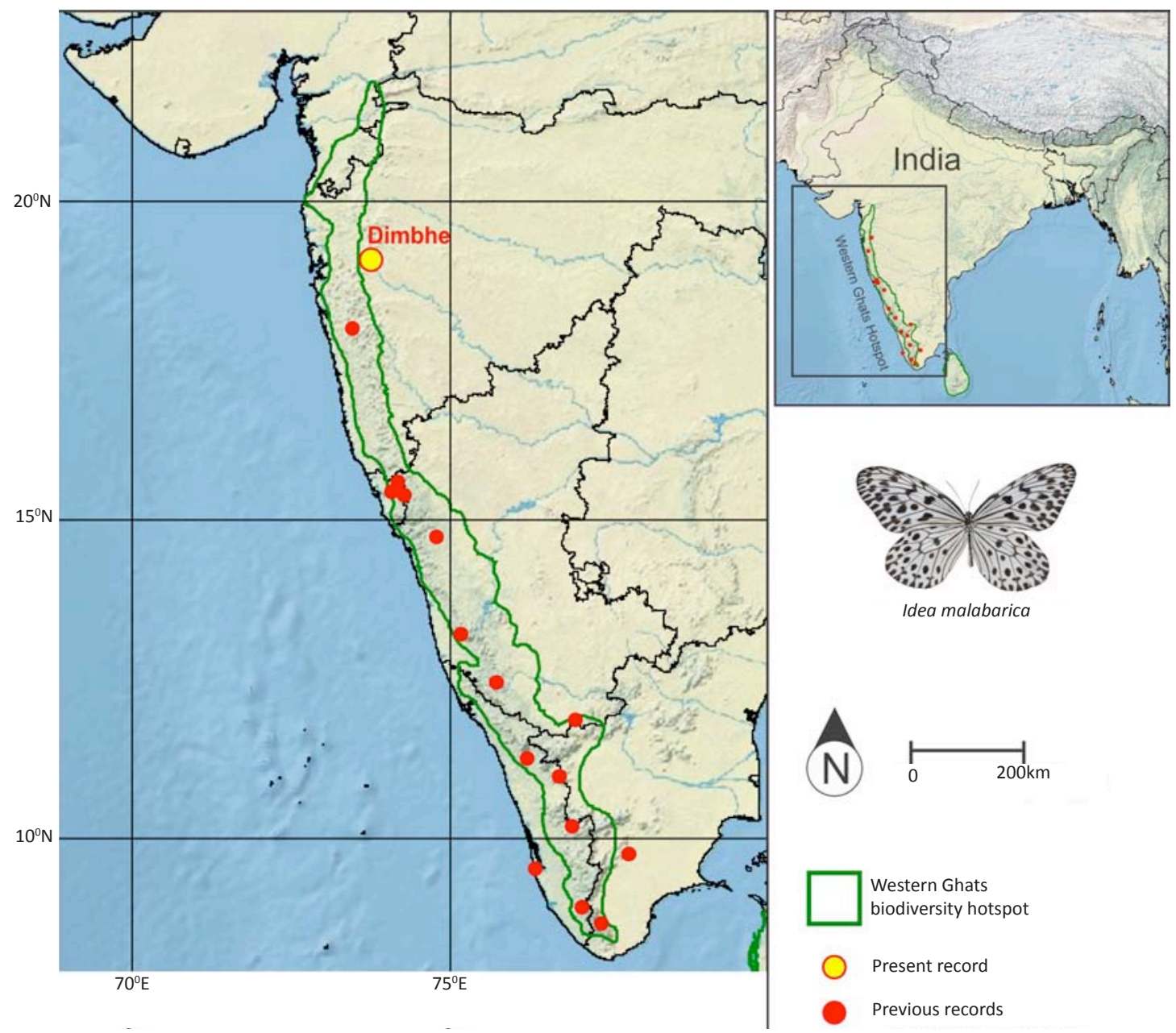

Image 2. Map of Western Ghats depicting distributional records of Idea malabarica Moore

Table-1. Indicating state wise distributional records of Idea malabarica Moore

\begin{tabular}{|c|c|c|c|c|c|}
\hline Sno & State & Locality & Latitude & Longitude & Reference \\
\hline 1. & \multirow{2}{*}{ Maharashtra } & Poladpur, Raigarh & $17.985^{\circ} \mathrm{N}$ & $73.466^{\circ} \mathrm{E}$ & Ghosh et al. (1990) \\
\hline 2. & & Dimbhe, Pune Dist. & $19.089^{\circ} \mathrm{N}$ & $73.743^{\circ} \mathrm{E}$ & Present record \\
\hline 3. & \multirow{3}{*}{ Goa } & Bhagwan Mahaveer Wildlife Sanctuary, Molem & $15.373^{\circ} \mathrm{N}$ & $74.258^{\circ} \mathrm{E}$ & $\begin{array}{l}\text { http://en.wikipedia.org/wiki/Bhagwan_- } \\
\text { Mahaveer_Sanctuary_and_Mollem_National_Park }\end{array}$ \\
\hline 4. & & Bondla Wildlife Sanctuary, Phonda & $15.437^{\circ} \mathrm{N}$ & $74.076^{\circ} \mathrm{E}$ & Borkar \& Komarpant (2004) \\
\hline 5. & & Brahma Karmali, Sattari & $15.569^{\circ} \mathrm{N}$ & $74.162^{\circ} \mathrm{E}$ & Rangnekar (2007) \\
\hline 6. & \multirow{3}{*}{ Karnataka } & Myristica Swamp, Uttara Kannada & $14.711^{\circ} \mathrm{N}$ & $75.730^{\circ} \mathrm{E}$ & Ali et al. (2004) \\
\hline 7. & & Coorg (Kodagu) & $12.426^{\circ} \mathrm{N}$ & $75.730^{\circ} \mathrm{E}$ & Kunte (2008) \\
\hline 8. & & Kudremukh National Park & $13.183^{\circ} \mathrm{N}$ & $75.148^{\circ} \mathrm{E}$ & Radhakrishnan \& Palot (2007) \\
\hline 9. & \multirow{3}{*}{ Tamil Nadu } & Siruvani Forest & $10.95^{\circ} \mathrm{N}$ & $76.716^{\circ} \mathrm{E}$ & Arun (2003) \\
\hline 10. & & Kalakkad-Mundanthurai Tiger Reserve & $8.65^{\circ} \mathrm{N}$ & $77.375^{\circ} \mathrm{E}$ & Dunston \& Raj (2005) \\
\hline 11. & & Selichandhai, Madurai & $9.724^{\circ} \mathrm{N}$ & $77.806^{\circ} \mathrm{E}$ & Alagumurugan et al. (2011) \\
\hline 12. & \multirow{5}{*}{ Kerala } & Krishnapuram Grama Panchayatha, Alappuzha & $9.497^{\circ} \mathrm{N}$ & $76.338^{\circ} \mathrm{E}$ & Radhakrishnan (2000) \\
\hline 13. & & Puyankutti Forest, Idukki & $10.166^{\circ} \mathrm{N}$ & $76.916^{\circ} \mathrm{E}$ & Arun \& Azeez (2003) \\
\hline 14. & & M.E.S. Mampad College, Mallapuram & $11.238^{\circ} \mathrm{N}$ & $76.196^{\circ} \mathrm{E}$ & Palot \& Abdurahman (2003) \\
\hline 15. & & Aralam Wildlife Sanctuary & $11.85^{\circ} \mathrm{N}$ & $75.966^{\circ} \mathrm{E}$ & Sreekumar \& Balakrishnan (2001) \\
\hline 16. & & Kulathupuzha Reserve Forest, Kollam & $8.908^{\circ} \mathrm{N}$ & $77.056^{\circ} \mathrm{E}$ & Ghosh \& Chaudhary (1986) \\
\hline
\end{tabular}


of Maharashtra, northern Western Ghats is available (Gaonkar 1996; Kunte 1997 \& 2001; Rane \& Ranade 2004; Padhye et al. 2006; Gaikwad et al. 2009; Sharma 2009; Aland et al. 2011). Padhye et al. (2012) presented latitudinal distribution of I. malbarica in Western Ghats. But it's occurrence in the range of $18-20{ }^{\circ} \mathrm{N}$ latitude is not yet reported.

Butterflies have specific habitat requirements depending upon their feeding and reproduction needs (larval host plants). Earlier, Idea malabarica was considered a monophagous species feeding on Aganosoma cymosa (Apocynaceae) but Susanth (2005) reported Parsonsia spiralis (Apocynaceae) as its new larval host plant. Nevertheless, it is not yet known out of two known host plants, which one is being used by the butterfly to survive in this area. However, it can be said with certainty that the sacred groves in the vicinity must include both host plants.

The record of Idea malabarica from Dimbhe, Pune District of northern Western Ghats, Maharashtra extends its known range significantly northwards from Raigarh (about $275 \mathrm{~km}$ ) and southern Western Ghats or Goa (about 530km). A distribution map (Image 2, Table 1) for Idea malabarica in Western Ghats is provided based on the published records (Ghosh \& Chaudhary 1986; Ghosh et al. 1990; Radhakrishnan 2000; Sreekumar \& Balakrishnan 2001; Arun 2003; Arun \& Azeez 2003; Palot \& Abdurahman 2003; Borkar \& Komarpant 2004; Ali et al. 2004; Dunston \& Raj 2005; Radhakrishnan \& Palot 2007; Rangnekar 2007; Kunte 2008; Alagumurugan et al. 2011).

The occurrence of Malabar Tree Nymph, an endemic butterfly of southern Western Ghats in the new geographical area is interesting to study: the factors which made the species extend its range to a considerable degree; to explore whether the butterfly is using other species of Apocynaceae as food plant in the study area and finding new areas conducive for its survival.

\section{REFERENCES}

Alagumurugan, C., M. Pavaraj \& M.K. Rajan (2011). Seasonal and relative abundance of butterflies in a scrub jungle habitat of Peraiyur Taluk, Madurai District, Tamilnadu. Journal of Research in Biology 1: 44-50.

Aland, S.R., A.B. Mamlayya, S.M. Gaikwad \& G.P. Bhawane (2011). Additions to the butterflies of Amba Reserved Forest of Kolhapur, Maharashtra. Bionotes 13(4): 162

Ali, S., M.D.S. Chandran \& T. V. Ramachandra (2004). Faunal assemblages in Myristica swamps of Central Western Ghats, Karnataka, India. Centre for Ecological Sciences, Indian Institute of Science. http://www. ces.iisc.ernet.in/biodiversity/sahyadri_enews/newsletter/issue23/ Article1/art4.htm. Date of accessed 07 July 2011.

Arun, P.R. (2003). Butterflies of Siruvani forests of Western Ghats, with notes on their seasonality. Zoos' Print Journal 18(2): 1003-1006.

Arun, P.R. \& P.A. Azeez (2003). On the butterflies of Puyankutty forests,
Kerala. Zoos' Print Journal 18(12): 1276-1279.

Borkar, M.R. \& N. Komarpant (2004). Diversity, abundance, and habitat association of butterfly species in Bondla Wildlife Sanctuary of Goa, India. Zoo's Print Journal 19(10): 1648-1653.

Dunston, P.A. \& D.S. Raj (2005). Butterflies of Kalakad-Mundanthurai Tiger Reserve, Tamil Nadu. Zoos' Print Journal 20(12): 2100-2107.

Evans, W. H. (1932). The Identification of Indian Butterflies $-2^{\text {nd }}$ Edition. Bombay Natural History Society, Bombay, x+454pp+32pls.

Gaikwad, S.M., S.R. Aland, A.B. Mamlayya \& G.P. Bhawane (2009). On the butterfly Diversity in Amba Reserved Forest of Kolhapur, Maharashtra, India. Bionotes 11(1): 26.

Gaonkar, H. (1996). Butterflies of the Western Ghats, India (including Sri Lanka). A biodiversity assessment of a threatened mountain system. Report to the Centre for Ecological Sciences, Bangalore (Unpublished).

Ghosh, S. K.. \& M. Chaudhary (1986). On the collection of Lepidoptera from the Silent Valley, Kerala. Records of the Zoological Survey of India 84(1-4): 107-119.

Ghosh, S.K., D.K. Mandal \& M. Chaudhary (1990). Butterflies of Maharashtra and Karnataka, India. Records of the Zoological Survey of India 86(1): 15-38.

Kehimkar, I. (2008). The Book of Indian Butterflies. Bombay Natural History Society and Oxford University press, New Delhi, xvi+497pp.

Kunte, K. (1997). Seasonal patterns in butterfly abundance and species diversity in four tropical habitats in northern Western Ghats. Journal of Bioscience 22(5): 593-603.

Kunte, K. (2000). Butterflies of Peninsular India. University Press (Hyderabad) and Indian Academy of Science (Bangalore), xviii+254pp.

Kunte, K. (2001). Butterfly diversity of Pune City along the human impact gradient. Journal of Ecological Society 13-14: 40-45.

Larsen, T.B. (1987). The Butterflies of the Nilgiri Mountains of Southern India (Lepidoptera: Rhopalocera). Journal of the Bombay Natural History Society 84(2): 291-316.

Padhye, A.D., N. Dahanukar, M. Paingankar, M. Deshpande \& D. Deshpande (2006). Season and landscape wise distribution of butterflies in Tamhini, northern Western Ghats, India. Zoos' Print Journal 21(3): 2175-2181.

Padhye, A., S. Shelke \& N. Dahanukar (2012). Distribution and composition of butterfly species along the latitudinal and habitat gradients of the Western Ghats of India. Check List 8(6): 1196-1215.

Palot, M.F. \& O.P. Abdurahman (2003). Butterfly collection at Entomology Museum, M.E.S. Mampad College, Kerala. Zoos' Print Journal 18(10): 1229-1231.

Radhakrishnan, C. (2000). Butterflies of Krishnapuram Grama Panchayat, Alappuzha District, Kerala - a case for revised study. Zoos' Print Journal 15(2): 202.

Radhakrishnan, C. \& M.J. Palot (2007). Insecta: Lepidoptera: Rhopalocera. Fauna of Kudremukh National Park, Conservation Area Series 32: 7196.

Rane, N.S. \& S.P. Ranade (2004). Butterflies of Tamhini-Dongarwadi area, Mulshi, Maharashtra. Zoos' Print Journal 19(3): 1411-1413.

Rangnekar, P. (2007). A Photographic Guide to Butterflies of Goa. Mineral Foundation of Goa, 66pp.

Sharma, R.M. (2009). Insecta: Lepidoptera: Rhopalocera and Grypocera. Fauna of Bhimashankar Wildlife Sanctuary, Conservation Area Series 42: 257-262.

Sharma, R.M. \& M.R. Borkar (2008). Insecta: Lepidoptera: Rhopalocera and Grypocera. Zoological Survey of India, Fauna of Goa State, State Fauna Series 16: 199-210.

Sreekumar, P.G. \& M. Balakrishnan (2001). Habitat and altitude preferences of butterflies in Aralam Wildlife Sanctuary, Kerala. Tropical Ecology 42(2): 277-281.

Susanth, C. (2005). Parsonsia spiralis: New larval host plant of endemic butterfly Malabar Tree Nymph, Idea malabarica Moore (Danainae, Nymphalidae). Journal of the Bombay Natural History Society 102 (3): 354-355.

Wynter-Blyth, M.A. (1957). Butterflies of the Indian Region. Bombay Natural History Society, Bombay, $\mathrm{xx}+523 \mathrm{pp}+72 \mathrm{pl}$. 